\title{
A fascination with plants
}

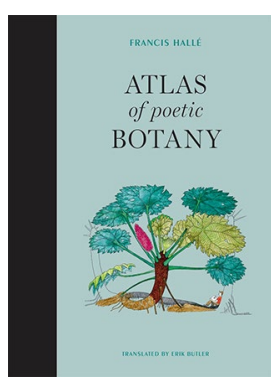

\section{The Atlas of Poetic Botany}

\section{By Francis Hallé (Translated by Erik Butler)}

MIT PRESS: 2018.

128 pp. $\$ 24.95$.

rancis Hallés The Atlas of Poetic Botany is a delightful read, with charming illustrations that exude the author's passion for botany and discovery. Featured throughout are the author's own sketches, studied while out in the field in most cases, which highlight the curious aspects of each plant - the size and other, small details (or in some cases, very large details) - that fascinated him.
Alongside these visual representations of each plant, the encyclopaedia also presents concise but detailed backgrounds as well as charismatic anecdotes. Despite the title there are no poems; rather, this book is like listening to an old friend speaking of their travels. You'll learn about the $28 \mathrm{~m}$-long leaves of the Raphia regalis (trees that can walk), how seringueiros fix a flat tyre in the middle of the Amazon and Henry Ford's failed tree plantation, to name just a few.

Hallés book is a physical manifestation of the places that he has explored, the wonders he has seen and the people he has met along the way; experiences most people will never have in their lifetime. This book has a colloquial yet informative manner while telling stories from many corners of the world. At one point in 1989, Hallé visited 'the dancing plants' (Codariocalyx motorius) in China, delighting in the fact that the plants danced to his French sea shanty tune. He evidently also delighted the locals as he left China with a gift of seeds, thereby enabling 'the dancing plants' to be grown in a greenhouse of the botanical gardens of Les Cèdres, Saint-Jean-Cap-Ferrat, France, for others to enjoy.

The Atlas of Poetic Botany is not only an insight into a variety of remarkable plants, but also into Hallés passion and love for botany and travel, which is evident within each page. His well-observed illustrations and easy-to-digest commentary make for an enjoyable read for people of all backgrounds. A lovely addition to any bookshelf.

Reviewed by Lauren Heslop

Published online: 9 September 2019 https://doi.org/10.1038/s41477-019-0517-6 